\title{
Role of Beach Morphology in Wave Overtopping Hazard Assessment
}

\author{
Benjamin T. Phillips ${ }^{1,2, *}$, Jennifer M. Brown ${ }^{2}$, Jean-Raymond Bidlot ${ }^{3}$ and Andrew J. Plater ${ }^{1}$ \\ 1 Department of Geography and Planning, School of Environmental Sciences, University of Liverpool, \\ Roxby Building, Chatham St., Liverpool L69 7ZT, UK; gg07@liverpool.ac.uk \\ 2 National Oceanography Centre, Joseph Proudman Building, 6 Brownlow St., Liverpool L3 5DA, UK; \\ jebro@noc.ac.uk \\ 3 European Centre for Medium-Range Weather Forecasts, Shinfield Park, Reading RG2 9AX, UK; \\ jean.bidlot@ecmwf.int \\ * Correspondence: b.t.phillips@liverpool.ac.uk; Tel.: +44-151-795-4816
}

Academic Editor: Dong-Sheng Jeng

Received: 18 August 2016; Accepted: 19 December 2016; Published: 5 January 2017

\begin{abstract}
Understanding the role of beach morphology in controlling wave overtopping volume will further minimise uncertainties in flood risk assessments at coastal locations defended by engineered structures worldwide. XBeach is used to model wave overtopping volume for a 1:200 year joint probability distribution of waves and water levels with measured, pre- and post-storm beach profiles. The simulation with measured bathymetry is repeated with and without morphological evolution enabled during the modelled storm event. This research assesses the role of morphology in controlling wave overtopping volumes for hazardous events that meet the typical design level of coastal defence structures. Results show that disabling storm-driven morphology under-represents modelled wave overtopping volumes by up to $39 \%$ under high $H_{S}$ conditions and has a greater impact on the wave overtopping rate than the variability applied within the boundary conditions due to the range of wave-water level combinations that meet the 1:200 year joint probability criterion. Accounting for morphology in flood modelling is therefore critical for accurately predicting wave overtopping volumes and the resulting flood hazard and to assess economic losses.
\end{abstract}

Keywords: sea defence breaching; storm morphology; wave overtopping; XBeach; flood hazard; joint probability; beach morphodynamics; wave modelling

\section{Introduction}

For storm events at and beyond the design level of modern, engineered flood defences, it is expected that the defence will experience partial wave overtopping or infiltration through the defence materials by high water levels. This may lead to breaching, which is the reduction of a defence's effective crest height, where flood water propagates through gaps in the defences as a result of structural failure. Once overtopping is replaced by significant breaching, inflow volume to the floodplain can increase by orders of magnitude [1].

The consequences of these increases in inflow volume to the floodplain have been demonstrated by Hurricane Katrina, where approximately $84 \%$ of the Greater New Orleans flood extent entered through breaches [2], some of which were up to $622 \mathrm{~m}$ in length [3]. Due to high flood velocity in the vicinity of breaches, there is an increase in the dangers associated with flooding, such as instability, drowning and impact from debris and building collapse [4]. These additional risks were clear in the U.K. during the 1953 North Sea floods, when defences were breached in 1200 places [5]. Here, the highest densities of casualties were found to be associated with their proximity to a sea defence breach [6]. On Canvey Island, 56 out of the 58 people who died during the 1953 floods were in close 
proximity to a breach [7]. These increased risks reinforce the need for effective flood risk assessment to account for risks of inundation from sea defence breaching.

The morphological response of a beach to storm events has been shown to be mostly dependent on wave action $[8,9]$, with other parameters including surge duration, pre-existing morphology and still water level also being capable of influencing storm-driven morphodynamics $[10,11]$. This research aims to determine the role of the initial beach profile and storm-driven changes in beach morphodynamics in controlling wave overtopping volume through a sea defence breach. This study models selected joint probability extreme wave-water level combinations with fixed pre- and post-storm morphologies (see Section 2.2) and time-evolving morphology. Determining the role of morphology in controlling wave overtopping is important for coastal managers to monitor and manage beach profiles to maximize their natural coastal resilience function and to inform model setup for flood risk assessment.

\subsection{Controls on Breaching}

The majority of breach-triggering mechanisms can be captured under three main headings, with excessive wave overtopping being the most common mechanism for breach initiation [12,13]:

- Hydraulic failure: overtopping damage causing significant erosion or scouring to the landward side.

- Geo-hydraulic failure: porewater-related effects, such as erosion of the internal structure through seeping.

- Global static failure: pressure forces (ice, wind, waves) exceeding the structure's resistance.

Breaching dynamics have been extensively researched and are characterised by an initiation phase followed by a growth phase. Inflow discharge to the floodplain is dependent on both of these phases. Two unique erosional processes, hydraulic erosion and slumping, are large controls on breach growth [14]. Any erosion-resistant defence, such as a concrete sea wall with an in situ stepped concrete revetment (used as the breaching case study here), can restrict breach initiation by hindering erosion and down-cutting. This applies even when a breach has been initiated, as it reduces the severity of slumping on cracks in the defence. A concrete foundation or an underlying more resistant geological substrate can also reduce breach expansion [1]. Morphological response during Hurricane Sandy was shown to be largely dependent on sea defence condition, where wave attack on Bay Head was shown to be a factor of 1.7 less with the seawall present, due to the prevention of $15 \mathrm{~m}$ of vertical dune erosion [15].

The hydraulic gradient (the difference between the extreme water level relative to the surrounding floodplain) is the initial driver of flow across the coastal floodplain. The higher the hydraulic gradient, the faster the flow of flood water and the more severe the erosion. Flow velocities gradually decay due to a reduction in the hydraulic gradient as a result of repeated erosion and slumping. The elevation and extent of the coastal floodplain ultimately controls the maximum breach size, as this determines the extent to which the original hydraulic gradient persists during the expansion of the defence breach [1].

\subsection{Flood Risk Modelling}

In the context of this study, joint probability refers to significant wave height $\left(H_{s}\right)$ and water level (WL), of which astronomical tide and storm surge are components as these occur simultaneously to produce an extreme event and potentially cause coastal inundation [16]. It is necessary to consider the joint probability of the two variables in flood risk management and coastal engineering, as it provides a more realistic understanding of a defence's resilience under various $H_{S}-W L$ combinations, which together have the same probability of occurrence. Noticeable differences in inundation extent and flood hazard can arise from different $H_{s}$-WL combinations, that have the same probability of occurrence [17]. Therefore, a joint probability approach is more suitable for flood risk assessment when compared with independent, univariate consideration of $H_{S}$ and WL. Considering that excessive wave overtopping is the predominant cause of sea defence breaching [13], joint probability analysis can also reduce uncertainty in developing fragility curves for various types of sea defence. 
A key component of flood risk analysis is breach dimension, as this is a key control on flood outcome and inundation extent $[18,19]$. Studies have attempted to model breaching dynamics that result from wave impacts on the seaward slope [20] and landward side [21]. Further studies have attempted to contextualise sea defence breaching within an integrated flood risk analysis [22,23] and to derive thresholds for storm events based on morphological thresholds [24].

Early wave overtopping models were one-dimensional and empirically derived, where beaches are assumed to be impermeable. Early numerical one-dimensional models to solve cross-shore sediment transport formulation include $[25,26]$. Two-dimensional models capable of solving along-shore sediment transport, erosion and time-varying wave overtopping on sandy beaches have also been developed [27]. Previous research has focussed on storm-driven hydrodynamic and morphodynamic changes on gravel beaches [28,29], where the applied model (XBeach-G) was shown to accurately predict initial wave overtopping and wave run-up. Similar studies have been applied for sandy beaches [30,31] and barrier beaches, where one-dimensional wave overtopping models were shown to yield reasonable predictions of $0.72-0.87$ ( $R^{2}$ value) when validated against field data of wave overtopping rates [32].

More recent improvements in accounting for storm-driven changes in beach morphodynamics in academic studies have moved beyond assuming a fixed beach profile, for example with SWAB (Shallow Water and Boussinesq, developed by [33]) [34], to accounting for gravel barrier response using XBeach-G [17]. This study quantified uncertainty in terms of flood hazard and inundation extent from various $H_{s}$-WL scenarios with the same annual joint probability for a gravel beach morphology and found that the greatest flood hazard is posed by a swell wave regime under high water levels [17]. However, this conclusion is heavily dependent on the prevailing wave climate and cannot be safely extrapolated to areas, such as the Irish Sea, that are wind wave dominant. Our study addresses the need to understand the uncertainties regarding storm-driven morphodynamics under joint probability forcing conditions and sea defence breaching. The approach presented focuses on the use of datasets available to coastal managers to help inform them of the appropriate model setup required when performing flood risk assessments that use coastal impact models.

\subsection{Site Selection}

Given that estimates of population residing less than $1 \mathrm{~m}$ above sea level range from $1 \%-2.3 \%$ of the total global population [35], there is a global need to understand breaching dynamics. Following historical examples of sea defence breaching leading to fatalities in the U.K. (e.g., the North Sea floods of 1953), we use a case study in a location that is vulnerable to wave overtopping and has recently experienced it during the winter 2013/2014 storms [36]. The selected frontage for this study extends from Rhyl to Prestatyn in North Wales, U.K. (Figure 1). The area experiences a macrotidal regime, with a mean spring tidal range of $7.20 \mathrm{~m}$ [37]. The wave climate is dominated by wind waves generated in the eastern Irish Sea, where significant wave height is less than $5.5 \mathrm{~m}$ and peak period is less than $12 \mathrm{~s}$, and there is an absence of swell waves due to limited fetch conditions [38]. This region of North Wales lies within a low and expansive coastal floodplain and has experienced inundation exacerbated by sea defence breaching. The most notable example of this is the Towyn flood in 1990. During this event, $467 \mathrm{~m}$ of sea wall were breached by a 1:500 year extreme water level [39], composed of high tides, a 1.3-m storm surge and $4.5 \mathrm{~m}$-high waves. Previous beach erosion coupled with poor maintenance of the sea defences resulted in a lack of protection and waves having maximum impact on the sea wall. The flood extent reached up to $2 \mathrm{~km}$ inland up to a depth of $1.8 \mathrm{~m}$ due to the expansive, low lying nature of the floodplain.

A more recent example occurred in December 2013 at Garford Road in Rhyl where significant wave overtopping led to the breaching of a secondary sea defence, allowing flood water to propagate into properties [36]. Garford Road in Rhyl serves as the location for the breach in this study given the flooding in December 2013, its poor condition (Grade 4) and its eroding beach [36]. The defences here comprise an in situ concrete sea wall, with a stepped concrete revetment and rear recurved wall 
and were constructed in the 1950s. Low beach levels could exacerbate the probability of a sea defence breach, by enabling scouring at the toe of the structure, which is the most likely failure mechanism for a vertical sea wall [40]. Other issues with flood risk management here include poor drainage of Rhyl Golf Links, where flood waters drained towards properties or remained on the golf course for several months [41]. In terms of morphology, the beach exhibits a nearshore swash bar system. Such features are common in wave-dominant regions of large tidal range and influence storm wave impact [42]. The location is therefore suitable to test the impacts of fixed morphology during storm conditions on wave overtopping and breach inflow volumes within flood risk assessment models, typically used to inform shoreline management plans. Given these factors and that flood risk here is driven by storm tides enabling wave overtopping, this section of defence is appropriate for addressing our research aims.

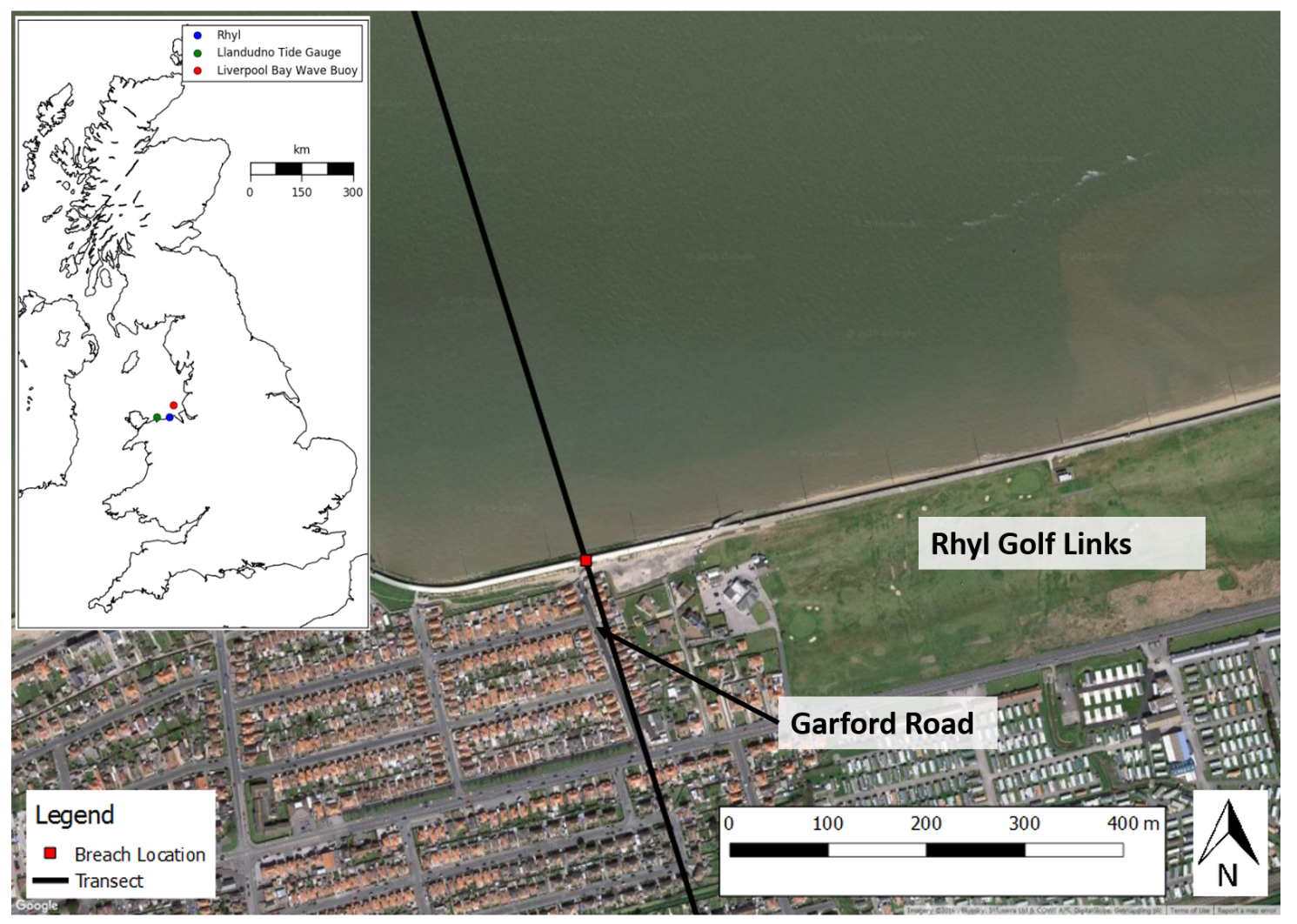

Figure 1. Satellite imagery of the study area, the breach at Garford Road and Rhyl Golf Links [43] and the location of Rhyl, Llandudno Tide Gauge and Liverpool Bay Wave Buoy within the U.K.

\section{Modelling Approach}

To simulate the flood hazard, a storm impact model (XBeach, October 2015 "Kingsday" version) is applied in non-hydrostatic mode to the observed beach profile at Garford Road (Figure 1). This study utilises XBeach to model wave overtopping. XBeach solves coupled 2D horizontal equations for wave propagation, flow and sediment transport for wave and tidal boundary conditions [31]. Studies have shown XBeach to effectively hindcast storm impact, overwash and breaching on sandy beaches [30,31]. It has also been used in the operation of coastal impact forecasting systems to forecast when storm impact hazard thresholds are exceeded by hydrodynamic and wave conditions [44,45]. As the beach at Rhyl is composed of sand and a fixed sea wall, XBeach is a suitable model to use for this study as it can represent the variable and fixed evolution of the beach and sea wall, respectively. These sections describe the methods and data used to set up the transect and the boundary conditions used to force $\mathrm{XBeach}$, which is applied here as a $1 \mathrm{D}$ cross-shore profile model. 


\subsection{Joint Probability Extreme Water Level Dataset}

Joint probability analysis requires a dataset of $H_{s}$ at corresponding high waters, and to reduce uncertainty, the length of this dataset should be as long as possible. For this study, multiple datasets of measured and modelled data were combined to generate joint probability boundary conditions. The Environment Agency methodology recommends using the Llandudno tide gauge for the study area [46], the tide gauge record for which extends from 1994-2015. The Liverpool Bay wave buoy, deployed and maintained by Centre for Environment, Fisheries and Aquacultural Science (CEFAS), provides a 13-year record from 2002-2015. Here, we use data from a rerun of the European Centre Wave Model (ECWAM, [47]) Cycle 41R1 (28-km resolution) to provide a longer dataset. The model is forced by a six hourly ERA-interim wind field with no wave data assimilation. The effect of water level change and surface current due to tides and surge is negated. The output used is hourly $H_{s}$ and $T_{p}$ from 1979-2014 and was extracted from the offshore limit of the XBeach boundary. This global hindcast was produced in preparation of the ECMWF (European Centre for Medium Range Weather Forecasts) next reanalysis (ERA5). This allows us to utilise a longer data record, from 1994-2014, in our joint probability analysis. Significant wave heights that exceeded $4.89 \mathrm{~m}$ were excluded from the joint probability inputs as these were rare and in some cases over-estimated due to the coarse resolution of the model, causing the joint probability analysis to become skewed. This upper limit ensures that the applied modelled $H_{s}$ are within the maximum 5.5-m conditions for this region, as determined by [38]. The ECMWF wave hindcast exhibits an RMSE (root mean square error) of $0.31 \mathrm{~m}$, a bias (the difference between the estimator's expected value and the true value of the parameter being estimated) of $0.06 \mathrm{~m}$ and a symmetric slope value of 1.11 for $H_{s}$ when validated against the Liverpool Bay Wave Buoy. For each high water, the closest $H_{s}$ and $T_{p}$ were extracted. The JOIN-SEA software uses the generalised Pareto distribution (GPD) model and simultaneous records of $H_{s}, \mathrm{WL}$ and $T_{p}$ (handled within a wave steepness variable) to calculate joint probability extreme water levels. $H_{s}$ and WL are transformed to normal scales using the generalised Pareto distribution model to values greater than specified thresholds [16]. An empirical distribution function is applied to values below this threshold. A single bivariate-normal distribution is then used to determine the dependence between $H_{S}$ and WL. A large range of synthetic records containing the same statistical properties as the original inputs is then simulated, and the exceedance of $H_{s}$-WL thresholds for specified return periods is calculated in the form of a distribution curve. For this study, we use a 1:200 year or a $0.5 \%$ probability event, as the Natural Resources Wales flood maps demonstrate Garford Rd. as being at risk from this severity of event if flood defences were not present [48].

In order to understand the role of morphology in controlling wave overtopping volume across the joint probability curve, we first identified the $H_{s}$-WL combinations that caused wave overtopping. We found wave overtopping to occur between a $2.99 \mathrm{~m}$ above Ordnance Datum Newlyn (m ODN) WL and $5.75 \mathrm{~m} \mathrm{H}_{s}$ (where the water level is sufficient to allow large waves to impact the defence) and 5.12 $\mathrm{m} \mathrm{ODN} \mathrm{WL}$ and $1.5 \mathrm{~m} \mathrm{H}_{s}$ (where $H_{s}$ is insufficient in causing wave overtopping despite elevated WL). To select suitable scenarios to test the impacts of morphology, we used scenarios with two identical WLs to allow the direct comparison of morphological variability under varying $H_{s}$ only (Table 1 ). This section of the joint probability distribution represents the tipping point between water levels allowing waves to overtop the sea wall and elevated water levels allowing smaller waves to cause overtopping. Storm-driven morphology impacts have been shown to be mostly dependent on high intensity wave energy [24] and the morphological variability under different conditions representing the same storm severity. The maximum recommended wave height with which to force XBeach is $5 \mathrm{~m}$ and is therefore not exceeded by our boundary conditions. 
Table 1. $H_{s}-\mathrm{WL}$ combinations extracted from the 1:200 year joint probability curve. Time-integrated overtopping volumes are provided from scenarios with morphological beach evolution enabled. Scenario 3 is shown in bold, as this was used as the most extreme forcing for the breach event, and for the extraction of pre- and post-storm profiles. MHWST, mean high water spring tide.

\begin{tabular}{ccccc}
\hline Scenario & WL $(\mathbf{m}$ ODN) & $\boldsymbol{H}_{\boldsymbol{s}}(\mathbf{m})$ & Overtopping Volume $\left(\mathbf{m}^{3}\right.$ per $\left.\mathbf{m}\right)$ & Skew Surge above MHWST $(\mathbf{m})$ \\
\hline 1 & 4.56 & 5.00 & 8089 & 0.73 \\
2 & 4.56 & 4.75 & 7701 & 0.73 \\
3 & 4.80 & 4.00 & 9244 & $\mathbf{0 . 9 7}$ \\
4 & 4.80 & 3.75 & 8755 & 0.97 \\
\hline
\end{tabular}

Joint probability analysis has been applied to historic high waters using data from Llandudno tide gauge and Liverpool Bay wave buoy. The joint probability analysis created a 1:200 year return period curve, shown in Figure 2. In this study, we present results for conditions that pose the greatest flood hazard, given in Table 1. Their selection is in agreement with other studies or previously-observed flood events that occurred due to defence overtopping and breaching. For the high water of 26 February 1990 (12:00), a water level of $6.13 \mathrm{~m}$ ODN (univariate return period of 1:80 year) coincided with a $4.32 \mathrm{~m}$ $H_{S}$ (univariate return period of one in 1.5 years). When considered in joint probability, this event can be classified as a 1:500 year return period [39]. The same analysis is provided for the high water of 5 December 2013, when a 1.09-m surge coincided with a spring tide of $5.13 \mathrm{~m}$ ODN and $4.55 \mathrm{~m} H_{s}$. The univariate probabilities for the water level and wave heights were calculated as 1:44 year and 1:5 year, respectively. This extreme event may have exceeded 1:200 year when considered in joint probability [49]. Given that this event caused significant wave overtopping and the breaching of a secondary sea defence, a 1:200 year WL and the values extracted from our joint probability analysis can be considered appropriate in addressing our research aims.

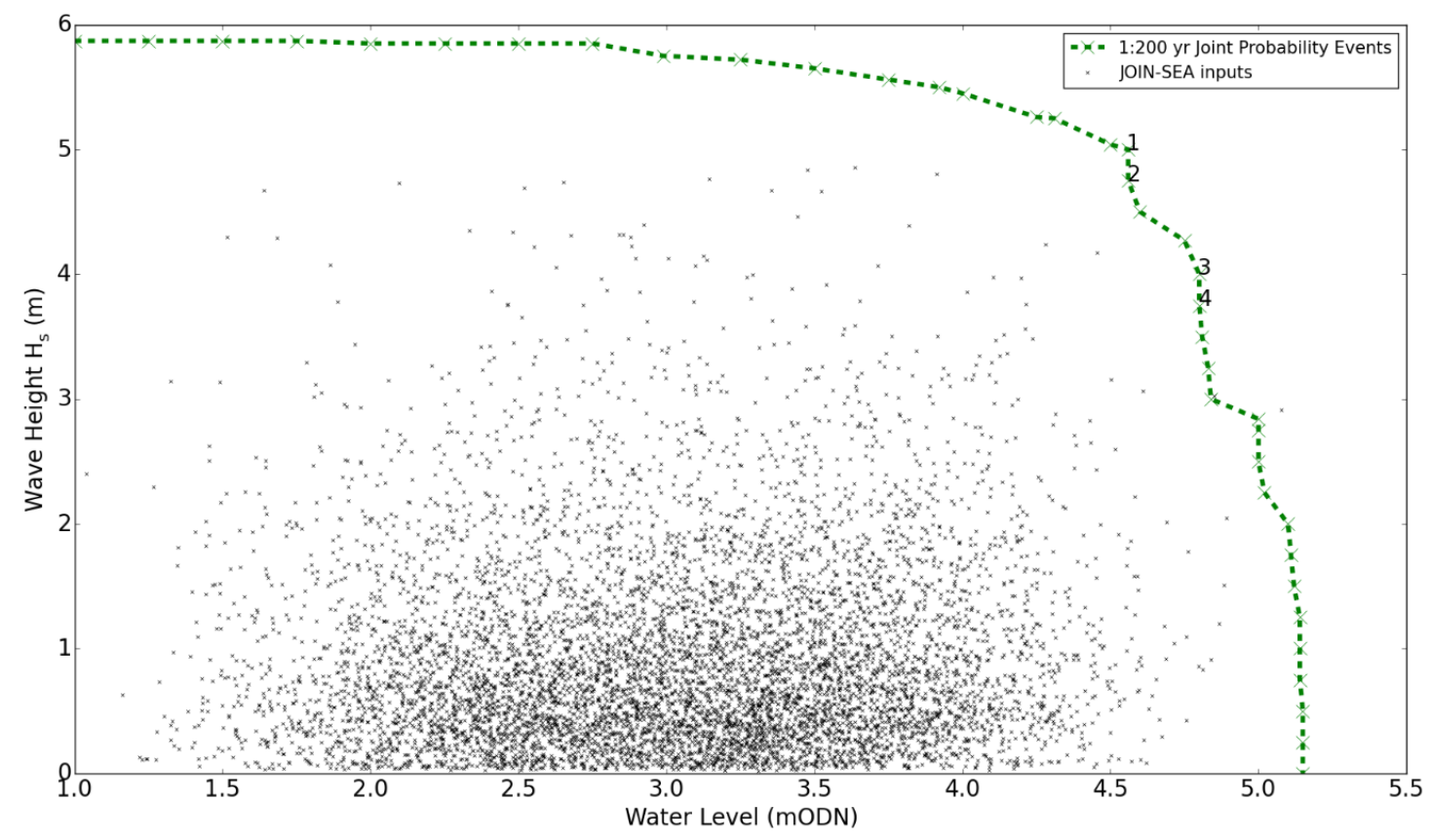

Figure 2. The 1:200 year joint probability distribution calculated from JOIN-SEA. Scenarios 1-4 are annotated, with specific parameters of these events shown in Table 1.

\subsection{Model Setup}

To generate tidal boundary conditions, we used Proudman Oceanographic Laboratory Tidal Prediction Software (POLTIPS) (provided by National Oceanography Centre Marine Data Products 
team) to identify a tidal cycle with a high water of $3.83 \mathrm{~m} \mathrm{ODN}$, as this is the mean high water spring tide (MHWST) for Llandudno for 2008-2026 [37]. The designed storm surge profiles for each Class A tide gauge across the U.K. are provided by the Environment Agency [46]. The designed surge profile from Llandudno is used to scale the MHWST curve to the required WL at 15-min temporal resolution. To do this, the difference between MHWST and the selected WL is calculated. These values were then multiplied by the normalised surge ratio and added to the tidal predictions to generate a time-varying storm tide. We use the peak tidal cycle of $12.5 \mathrm{~h}$ rather than the full $99-\mathrm{h}$ profile, as overtopping is likely to only occur around high water during a tidal cycle. Skew surges up to $1.01 \mathrm{~m}$ have been recorded at Llandudno (and up to $1.09 \mathrm{~m}$ at Liverpool), with at least 10 skew surges higher than $0.73 \mathrm{~m}$ occurring since 1996 [50]. The skew surge values required to obtain the appropriate WLs (see Table 1) do not exceed any skew surges on record and are therefore suitable for this study. Given that our aim is only to test the role of morphology, the peak surge and tidal high water are set to coincide following the methodology recommended by [46].

Along with water level boundary conditions, XBeach was forced with a constant $H_{s}$ and a $9.08 \mathrm{~s}$ $T_{p}$ using a JONSWAP (Joint North Sea Wave Project) spectrum, which was also kept constant for each of the morphological setups. $T_{p}$ was derived from the ECMWF hindcast; the chosen value is representative of the maximum $T_{p}$ associated with $H_{s}$ with similar values to those used in this study (Table 1). The maximum value is chosen to ensure maximum wave impact for overtopping. A constant $T_{p}$ is applied in each scenario to limit the overtopping variability between scenarios to only the $H_{s}-\mathrm{WL}$ conditions. Wave direction was not accounted for in the model boundary conditions, again to restrict the range of input parameters being varied to $H_{s}$-WL conditions alone. In each simulation, the waves are assumed to propagate directly onshore for maximum impact. A constant wave condition is applied to simulate the maximum hazard, reducing the complexity of having to represent the time-variability in wave conditions relative to the tidal elevations for events at this location.

By exploring a full range of profiles in relation to high water, we can gain a better understanding of total and time-varying wave overtopping volumes across the joint probability distribution. Post-storm profiles were selected to determine whether changes in morphology could lead to greater wave overtopping under storm conditions in subsequent tidal cycles. Pre-storm profiles were selected, as high, healthy beach levels damp approaching waves and promote breaking prior to impact. We selected the highest pre-storm beach level (Scenario 1) and the lowest post-storm beach level (Scenario 4) at the toe of the sea defence from all four $H_{s}$-WL scenarios as input bathymetries, to fully explore morphological variability. The variability between pre-storm and post-storm profiles is demonstrated in Figure 3 and shows reasonable agreement between profiles. The upper beach profiles of the smoothed pre- and post-storm profiles are representative of a more reflective and a more dissipative profile [51], respectively. The consideration of event-driven morphological evolution was also investigated to account for the potential impact of models that may not be capable of resolving morphological evolution, in order to understand the implications for flood modelling. XBeach was therefore used to test the following morphological settings and input profiles, which represent the possible combinations used by local authorities for coastal flood risk assessments:

1. A realistic (measured seasonal profile, Figure 3) nearshore swash bar system, extracted from the original 1D transect, with morphology disabled.

2. A realistic (measured seasonal profile, Figure 3) nearshore swash bar system, extracted from the original 1D transect, with morphology enabled.

3. Pre high water (transect extracted 33\% of the way through the XBeach simulation of Scenario 1, pre-storm, Figure 3), where the water level had begun to smooth the nearshore swash bar system to represent the pre-storm profile, with morphology disabled.

4. Post high water (transect extracted at the end of the XBeach simulation of Scenario 4, post-storm, Figure 3), to be representative of a post-storm beach profile, with morphology disabled.

XBeach contains several options for morphological evolution. To completely disable morphological evolution for the pre-storm, post-storm and actual, but fixed profiles, we entered "morphology = 0 " 
into the parameters file. XBeach also contains an option for allowing certain grid coordinates to remain fixed whilst others morphologically evolve. This approach is appropriate for the morphology enabled scenario, where the sea wall is fixed, but the beach evolves through the simulation. Each grid point in the transect was set to a value of zero for non-erodible (i.e., the sea wall) or 10 for the beach. This file is then set under the "ne_layer" keyword in the parameter file. When running the model, the typical simulation time was approximately $8 \mathrm{~h}$, with a time step of $0.02 \mathrm{~s}$. Therefore, time steps were sufficiently small to capture overtopping events, which are in the order of seconds.

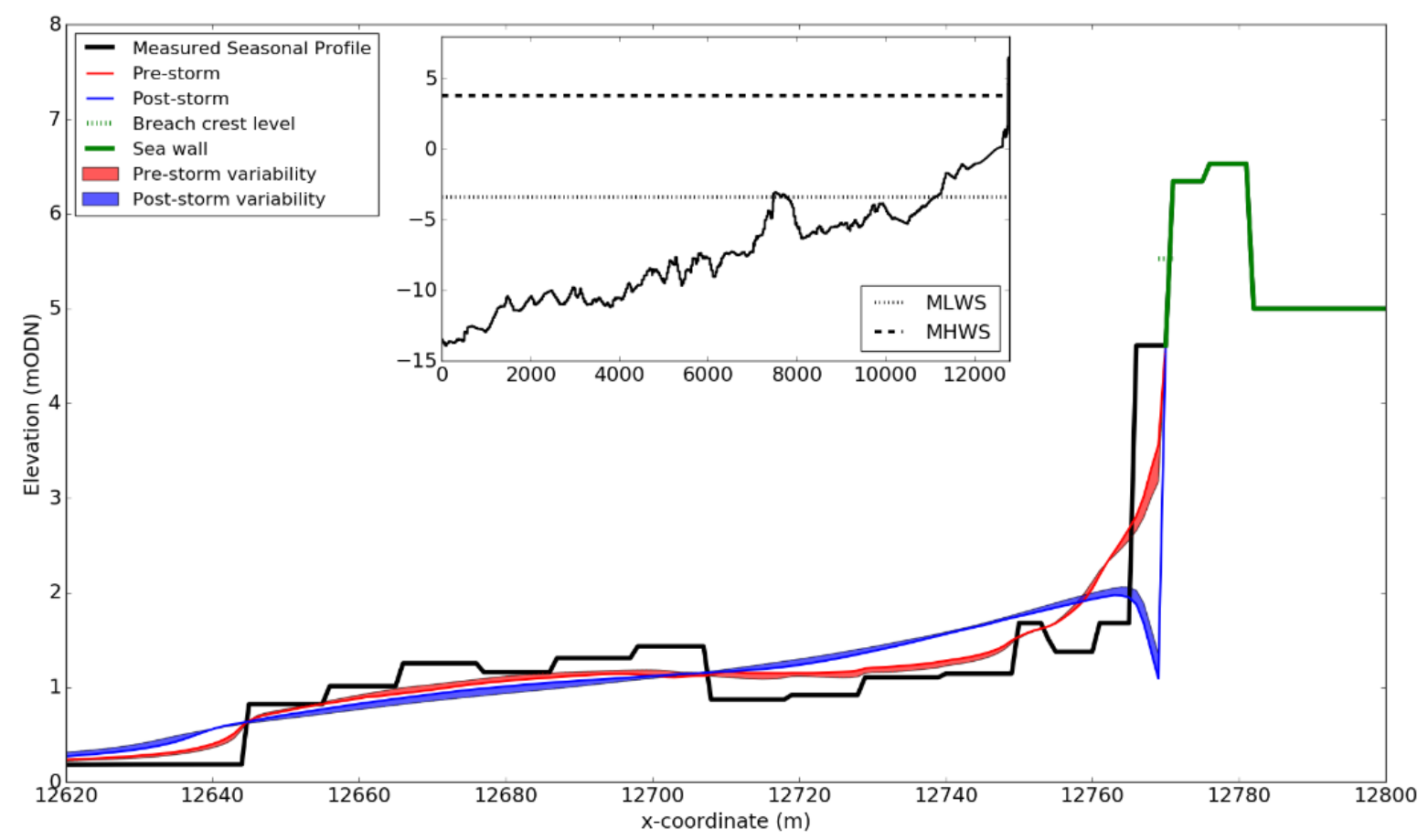

Figure 3. Applied 1D transect in XBeach, with all considered initial bathymetries. The post-storm variability (blue shading) shows the difference between the lowest (Scenario 4, Table 1, selected profile) and highest (Scenario 1, Table 1) elevation at the sea defence toe. The pre-storm variability (red shading) shows the difference between the lowest (Scenario 4) and highest (Scenario 1) elevation at the sea defence crest toe. Mean high water spring (MHWS) and mean low water spring (MLWS) tidal elevations are provided by [37].

The one-dimensional model transect ( $1 \mathrm{~m}$ wide) consisted of a combination of a nearshore topographic survey (carried out on 5 October 2010 using real-time kinematic GNSS in accordance with the then Environment Agency National Standard Contract and Specification for Surveying Services). The transect was extended by EDINA Digimap gridded bathymetry capturing depths up to approximately $-13 \mathrm{~m}$ ODN at $13 \mathrm{~km}$ offshore (see Figure 3), both at 1-m grid resolution. This offshore limit represents the locations at which the offshore wave hindcast for Rhyl was provided. Linear interpolation was used to ensure a smooth transition between the two datasets. Standard cross-shore discharge ( $Q x$ in XBeach) from the model output was used to calculate wave overtopping volume. The time-varying discharge for the defence crest was extracted and multiplied by the save interval $(5 \mathrm{~s})$ to convert into a volume. Using this approach means that applying a constant, planar value to the floodplain is an acceptable approach, as once the water is landward of the defence crest, it becomes irrelevant. Breaches were integrated by subtracting the loss of crest height from the crest elevation. 


\subsection{Modelling Sea Defence Breaching}

We impose a 1-m loss of crest height for the sea wall at 60, 30 and $15 \mathrm{~min}$ before high water, at high water and $15 \mathrm{~min}$ after high water. The bed profile, wave spectrum and water level from Scenario 3 were extracted at the time of the breach. The upper section of the pre-breach beach profile was modified to incorporate a lower crest level for the seawall. XBeach was then "warm started" at the time of breaching with the breached defence crest from the extracted pre-breach water level and wave spectrum, and the simulation continued for the remainder of the tidal cycle to simulate post-breach wave overtopping. A 5-s save interval was applied in XBeach, with results showing wave overtopping volume averaged out over $7.5 \mathrm{~min}$ (i.e., $1 \%$ of a tidal cycle). Wave overtopping did not occur more than 150 min either side of high water, so these sections of the tidal curve are excluded in the analysis of our results.

\section{Results}

\subsection{Beach Morphology under Wave Overtopping Scenarios}

Figure 4 clearly shows high variability in time-integrated total wave overtopping volumes between the scenarios, despite all having the same probability of occurrence. Disabling morphology on the measured bathymetry yields the lowest wave overtopping volume in every scenario. The pre-storm profiles exhibit the highest wave overtopping in each scenario. This is likely to be attributable to the smoothing of the nearshore swash bar (Figure 3), and the low elevations of the upper beach, before rapid steepening at the defence toe, allowing waves to break closer to the seawall. There is a negligible difference between the morphology enabled and post-storm profiles in all scenarios, suggesting that the cross-shore sediment transport rapidly redistributes sediment to form the post-storm profile. The variability in overtopping volume between the scenarios is much less when morphology is considered for the measured bathymetry than when it is not (black compared with white bars, Figure 4), with differences of $1542 \mathrm{~m}^{3}$ and $2363 \mathrm{~m}^{3}$ between the minimum and maximum volumes for morphology enabled and disabled, respectively. The variability in overtopping across the actual profile with enabled and disabled morphology is greater under Scenarios 1 and 2, which both experience greater wave action compared with Scenarios 3 and 4 (Table 1). Our results clearly demonstrate that, particularly under high $H_{s}$ conditions, excluding morphology considerably under-estimates wave overtopping volume by up to $2959 \mathrm{~m}^{3}$ and $3010 \mathrm{~m}^{3}$ under Scenarios 1 and $2,36 \%$ and $39 \%$ lower than the morphology-enabled wave overtopping volumes, respectively. This shows that morphological evolution has the potential to exert greater influence on the uncertainty of overtopping volumes than the choice of $H_{s}$-WL combinations representing the most extreme flood hazard conditions for the required event severity.

In addition to the total time-integrated wave overtopping volumes, there is important temporal variability in the time-varying wave overtopping across the scenarios (Figure 5). The largest variability occurs between $75 \mathrm{~min}$ before and $50 \mathrm{~min}$ after high water. The variability in wave overtopping is greatest for the pre-storm profile with morphology disabled. For this model setup, the greater overtopping volumes occur either side of high water in Scenario 2 and more noticeably in Scenarios 3 and 4 . This suggests that the increased WLs and lower waves enable an increase in wave reflection at high water, reducing the overtopping for this beach profile. The measured profile with morphology disabled has a continually low overtopping volume. This suggests that the morphological features and their evolution dampen the influence of the wave field variability as it propagates towards the shoreline. Variability in the overtopping duration is negligible across all scenarios, with overtopping occurring just earlier than $100 \mathrm{~min}$ before high water. The decay in overtopping volume occurs at a similar rate and time across all four scenarios each model setup. However, overtopping is seen to end just earlier than $100 \mathrm{~min}$ after high water, suggesting that the flood and ebb tides cause slight asymmetry in overtopping duration either side of high water. All scenarios display either peaks in wave overtopping either side of high water, typically occurring up to $50 \mathrm{~min}$ either side of high water, 
or little change in the maximum values during the 50 min either side of high water. This suggests there is competition between higher water levels limiting wave dissipation across the beach profile and deeper depths at the structure toe promoting wave reflection.

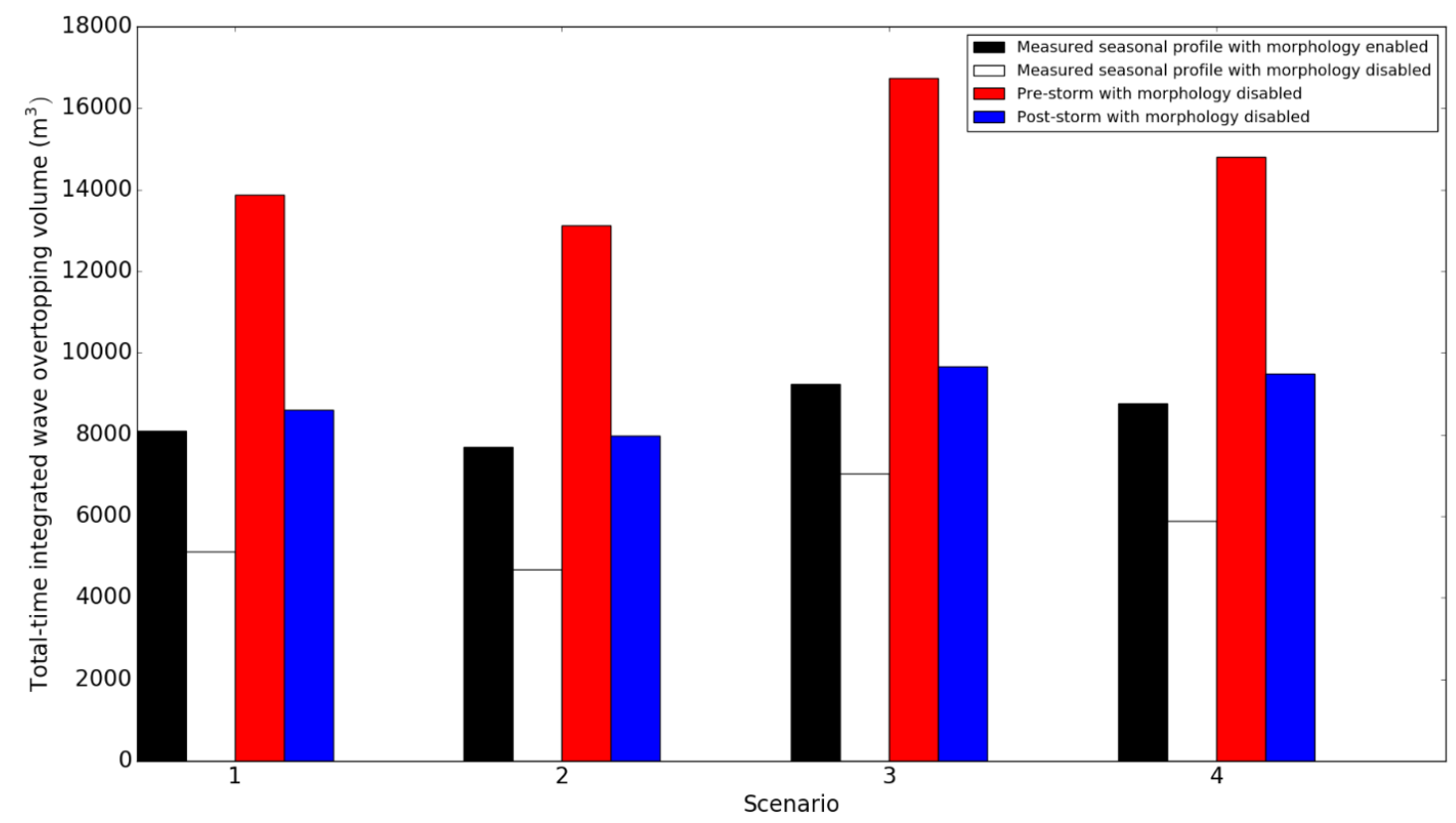

Figure 4. Total time-integrated wave overtopping for each scenario under the applied morphological profiles: measured seasonal profile with morphology disabled, measured seasonal profile with morphology enabled, pre-storm with morphology disabled and post-storm with morphology disabled.

In addition to temporal variability, morphological setting and initial input, bathymetry is shown to be a key control on maximum ( $5 \mathrm{~s}$ averaged) wave overtopping volume. In Scenario 2, the maximum wave overtopping during the pre-storm profile simulation is a factor of three higher than that of the morphology-disabled simulation. The morphological setting and initial input bathymetry have the potential to exercise larger control on wave overtopping volume compared to the applied $H_{S}-\mathrm{WL}$ condition. Noticeably, the morphology-enabled and post-storm profiles display similar temporal variability (particularly under Scenarios 2 and 4) and negligible difference in the total time-varying wave overtopping volumes. The difference in wave overtopping volumes between pre-storm and morphology-disabled profiles exceeds that of the applied $H_{s}$-WL conditions.

There is large temporal variability in time-varying scour (Figure 6, calculated as the difference in bed elevation at the grid point adjacent to the structure toe that is enabled to evolve and the adjacent seaward grid cell). Across all scenarios, scour reaches a maximum after high water as the wave action continues to erode the beach after high water. A comparison of Figures 5 and 6 shows that scour is initiated at approximately $80 \mathrm{~min}$ before high water just after the onset of wave overtopping. Scenario 3 experiences the most severe rate of scour at its onset, with almost no variability between Scenarios 1 and 2 from $105 \mathrm{~min}$ before high water and $90 \mathrm{~min}$ before high water. Scenario 4 scours at a more gradual rate. Either side of high water, there is a very variable response in scour level. However, after scouring is initiated, the final depth of the remaining scour hole after the tide has receded seems to be most sensitive to the water level. Higher water elevations enable the wave action to cause scour earlier and the resulting depth to be greater. The results do not suggest that higher water levels enable scour to continue for longer on the falling tide. 

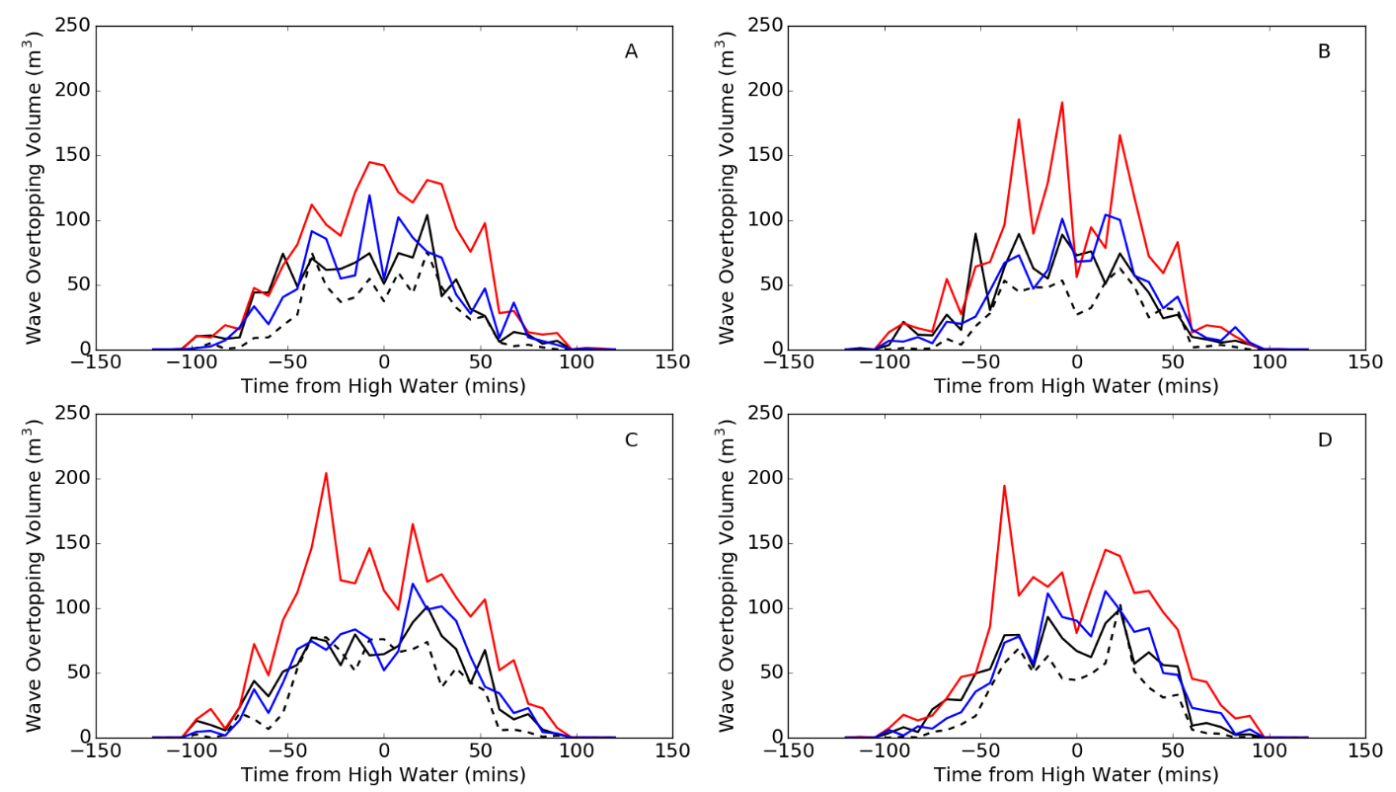

Figure 5. Time-varying wave overtopping for Scenario 1 (A), Scenario 2 (B), Scenario 3 (C) and Scenario 4 (D), under the applied morphological profiles: measured seasonal profile with morphology disabled (dashed black line), measured seasonal profiles with morphology enabled (solid black line), pre-storm with morphology disabled (red line) and post-storm with morphology disabled (blue line).

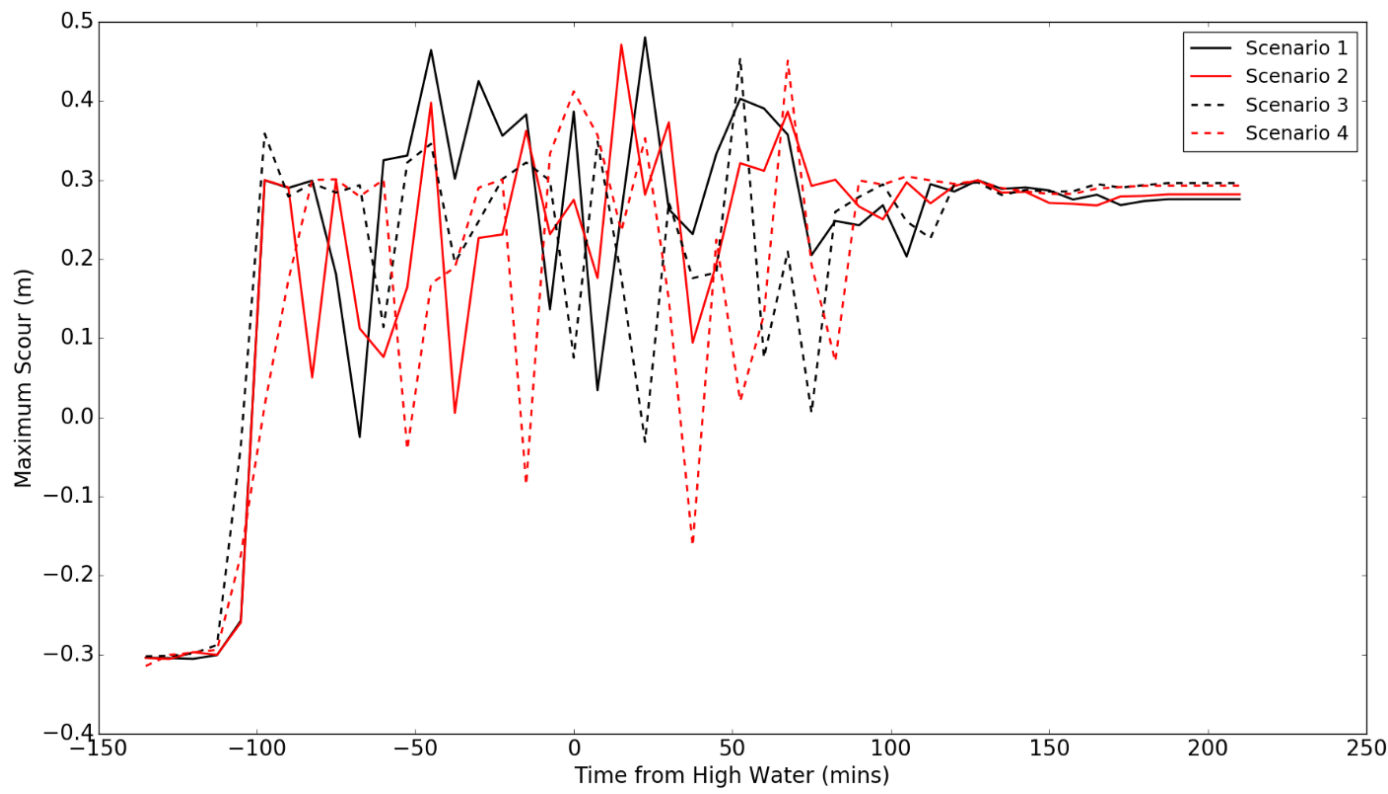

Figure 6. Time-varying scour at the toe of the structure (calculated as time-varying difference in elevation between x-coordinates 12,768 and $12,769 \mathrm{~m}$ ) for each scenario (see Table 1) with morphology enabled.

The maximum scour under Scenarios 1 and 2 occurs at 15 and 22 min after high water, respectively. The greater extreme water level influence relative to wave action under Scenarios 3 and 4 results in a similar level of maximum scour 50 and $65 \mathrm{~min}$ post high water. At approximately $130 \mathrm{~min}$ after high water, the scour is within $0.05 \mathrm{~m}$ across all four scenarios, until the ebb tide and wave run-up is no longer acting on the beach level at the defence toe and scour plateaus. Here, Scenario 1 (which has the greatest wave action) has resulted in the least resultant scour, with Scenario 3 causing the most 
resultant scour. Given that there is only a 0.02-m difference in resultant scour across all scenarios, it is not safe to conclude whether tide or wave action controls resultant scour. Accounting for various morphological responses from resultant scour remains important in determining wave overtopping volume on storm clusters occurring on subsequent tidal cycles.

\subsection{Beach Morphology under Sea Defence Breaching Scenarios}

Figure 7 demonstrates that breach timing and morphological setting have a large control on the time-integrated total wave overtopping volume for Scenario 3 (the $H_{s}$-WL combination with the highest overtopping volume, Table 1). The pre-storm profile displays the highest time-integrated total wave overtopping volume for every breach scenario and the morphology-disabled profile the lowest. There is minimal variability in wave overtopping volume between the post-storm and morphology-enabled profiles, particularly at high water. Except for the breach occurring $60 \mathrm{~min}$ before high water, wave overtopping for the measured morphology-enabled profile exceeds that of the post-storm profile. The post-storm and morphology-enabled profiles exhibit similar patterns in Figures 4 and 5, when no breach is applied.

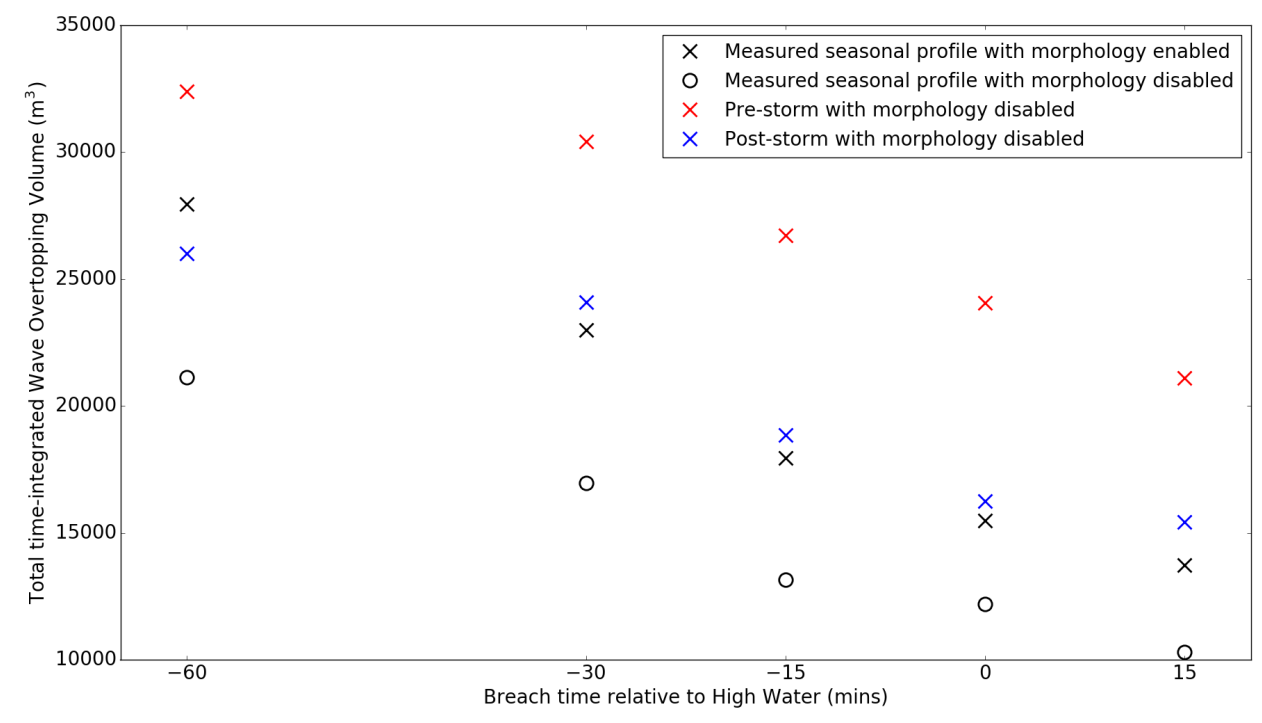

Figure 7. Total time-integrated wave overtopping volume for the duration of the event in Scenario 3 for each morphology setting with a 1-m breach applied at $-60,-30,0$ and $15 \mathrm{~min}$ from high water. Values represent total overtopping volumes for each breaching simulation, rather than cumulative overtopping through the event.

The breach occurring at $60 \mathrm{~min}$ before high water displays the highest cumulative wave overtopping volume; this can be attributed to the water level having more time to overtop the breached defence. There is a reasonably linear relationship between the breach time relative to high water and the total wave overtopping. A "tipping point" seems to exists between $30 \mathrm{~min}$ and $15 \mathrm{~min}$ before high water, after which the rate of reduction in wave overtopping volume is reduced, for all but the pre-storm profile, which shows an increased rate of reduction. The spread in the results becomes less when the breach occurs after high water. The different morphological settings clearly have an impact on the total time-integrated overtopping volume, despite the large additional discharge due to the breach (Figure 7 volumes compared with Scenario 3 in Figure 4). This further shows that careful selection of an appropriate initial bathymetry within a flood risk assessment model when morphological evolution of the beach is not considered is important. Here, it is again suggested that a post-storm bathymetry is more representative than the other fixed profile simulations at simulating 
the overtopping volume simulated for the measured profile with morphology enabled. Although, the error is greater than that of the no breach simulation.

\section{Discussion}

These scenarios and our method cannot be taken as a prediction of a past or future wave overtopping event; rather, they demonstrate the impact of beach morphology on wave overtopping volume under joint probability conditions representative of a 1:200 year event, coupled with sea defence breaching (where applicable). Previous research has primarily been concerned with exploring the impact of a joint probability distribution on inundation extent and flood hazard [17] without comparing the impact of various morphological settings to account for various models that may be applied by coastal managers. Hydrodynamic factors have been applied in a coastal flood forecasting system that parametrised beach levels using canonical correlation analysis (CCA) according to the incident wave conditions [52]. Whilst this may be more computationally efficient over a longer forecasting period, it negates the detailed representation of the time-varying event-driven morphological evolution. This may be an important uncertainty in areas where both tides and waves have a similar impact on morphological evolution. A numerical model, such as XBeach, accounts for the time-varying evolution of the beach profile and the feedbacks on the coupled wave-water level conditions, but is more computationally expensive.

Other studies assessed the overwash regime using multi-decadal time series in a similar coastal setting, but assumed a static morphology [53]. Such an assumption does not capture the potential uncertainty in the flood hazard due to event-driven morphological evolution. Studies using XBeach have been largely limited to studies of morphological evolution during storm conditions [30,42] and have not attempted to quantify the impact of these changes on wave overtopping volumes and the implications for coastal flood modelling.

XBeach has been compared with empirical models (EurOtop and "bathtub" method) in a validation of coastal flooding, where it was found to reasonable predict flood extent [54]. Rigorous validation of wave overtopping models requires inflow volume data rather than just resultant flood extents. It has been shown to yield reasonable predictions of breaching behaviour at Dungeness [55] and to reasonably predict storm morphodynamics on beach systems [44]. Combining appropriate joint probability boundary conditions to create an event of the desired hazard rating, with the understanding of the consequence of the chosen morphological setting and input profile, is therefore important for coastal stakeholders and policy makers to assess the potential range in impact of an extreme event.

\subsection{Impact of Morphology on Controlling Wave Overtopping}

Our results demonstrate that the influence of morphological forcing creates noticeable variability not only in the time-integrated total wave overtopping volume, but also creates temporal uncertainty in the timing of peak wave overtopping volume. Whilst understanding the temporal uncertainty surrounding the morphological controls on wave overtopping provides a critical insight for managing flood hazard, it is also important to consider the total volume of water, as this will be a key determinant of the total inundation extent and resulting economic cost caused by a flood event. Although we have only applied four scenarios, wind waves dominate the wave climate, and as such, the most severe wave overtopping occurs in the section of the joint probability curve chosen. Given that the variability in wave overtopping due to the representation of the beach morphology (in Scenarios 1 and 2) is considerably greater than the variability due to the considered $H_{s}-W L$ conditions, this demonstrates that the impact of morphology has the potential to create greater uncertainty in flood hazard for a storm of a given severity than the hydrodynamic boundary conditions that represent the storm conditions.

Sites are typically surveyed bi-annually (summer and winter) to capture the seasonal variability in beach elevation for shoreline management purposes. However, the timing of a survey relative to a storm may cause the profile to represent pre-storm, post-storm or partially-recovered conditions. 
We therefore indicate the potential uncertainty in a flood risk assessment when using limited available survey data. The variability in the pre- and post-storm profile wave overtopping rates also helps inform managers on profile resilience. Such information is important when considering beach nourishment and pre-winter hazard assessments. Here, a lower beach elevation with a steep gradient at the toe of the defence (as in the pre-storm profile) can allow greater overtopping than a beach face with higher elevations and no increase in elevation at the defence toe (or in this case, scour, as in the post-storm profile).

\subsection{Implications for Flood Modelling}

The noticeable variability in wave overtopping between the scenarios highlights the importance of accounting for uncertainty in $H_{s}-W L$ boundary conditions used to force a storm impact model. This reinforces the need for the consideration of joint probability extreme water levels to enable a range of conditions and inform suitable defence design [17]. This approach is being used in commercial studies, e.g., [56], and examples exist where joint probability for historical events is also calculated [57].

Our results clearly show that the applied morphological evolution has a large influence on not only the time-varying wave overtopping, but also the total volume overtopping the defence. A simple modelling approach of taking a nearshore topographic survey and applying a model exclusive of morphological updating is likely to significantly over-estimate or under-estimate the wave overtopping volume, depending on the chosen bathymetry. One with features, such as a nearshore swash bar system, will cause under-prediction, while a smoothed initial profile over-predicts, particularly when the upper beach face is imposed at a low elevation. This is particularly important under joint probability boundary conditions with higher $H_{s}$ and wave action, as Scenarios 1 and 2 demonstrate greater variability between the morphology enabled and disabled scenarios (up to $39 \%$ variability). The importance of accounting for beach morphology in the original transect is shown to be a large control on wave overtopping volume for inundation modelling, whether sea defence breaching occurs or not.

Regardless of the time occurrence of sea defence breaching, the impact of morphological representation during a sea defence breach event is shown to be just as critical as when the sea defence is only overtopped and particularly when the breach occurs more than $15 \mathrm{~min}$ before high water. This demonstrates that any flood modelling, even if inclusive of sea defence breaching where wave overtopping volume has the potential to increase by orders of magnitude, should account for the impact of storm-driven changes in morphology. Studies with clusters of storms occurring in close succession should use a morphology model to account for the recovery of features within the beach profile for accurate assessment of the clustered hazard. This has implications for the development of fragility curves, which may benefit from this type of modelling where impacts of beach changes over several tidal cycles on fragility curve inputs (i.e., difference between crest elevation and water level) can be observed. This approach of using multiple morphology forcings is more suitable to locations such as Rhyl, where a nearshore swash bar exists within the beach profile. Here, the flood hazard is due to water levels enabling large wind waves to overtop. Further study would be required to see if morphology is of higher importance than the representative $H_{s}-\mathrm{WL}$ boundary conditions under a bimodal wave regime, in posing a greater secondary flood hazard at higher water levels when the wave regime turns from wind waves to swell waves [17].

\subsection{Limitations of This Research}

The limitations we discuss are currently widespread due to data availability and are not exclusive to this study. Limitations of this research include the unimodal application of waves due to joint probability analysis providing only a single $H_{s}$-WL condition. This may result in the total wave overtopping volume being larger than expected. The relatively short record of $H_{S}$ and WL (20 years) limits the accuracy of calculating a 1:200 year probability distribution. ECWAM is not a shallow water model and therefore leads to occasional over-prediction of $H_{s}$ given the coarse resolution of both bathymetry and wind forcing. Considering wave direction would have presented a more 
realistic representation of wave run-up and beach profile response in the XBeach boundary conditions, but would have further shortened the joint probability dataset and further increased uncertainty. To overcome all of these limitations, a coastal area model could simulate long-term datasets of combined $H_{s}$-WL conditions; however, this is computationally demanding [17]. A single deterministic run is used for the four scenario settings, so any variability in overtopping volumes due to the representation of the wave field is not captured. Using an ensemble of simulations would give greater information on the variability in overtopping rates due to the variability in the wave field; however, using the same time-varying wave spectra for each simulation within the four $H_{s}$-WL scenarios ensures that the difference in overtopping volumes is due to the input profile and morphological setting.

\section{Conclusions}

We have demonstrated a method to use XBeach to determine the role of storm-driven changes in beach morphology under various joint probability $H_{s}$-WL combinations. We show that enabling beach morphology increases wave overtopping volumes during high flood hazard events with a one in 200 year severity, particularly under high $H_{s}$ conditions. This study further shows that the impact of enabling morphological evolution (either enabling morphology in the model or using a profile with smoothed pre-existing features) can have a greater impact on wave overtopping volume than variability in the applied extreme wave height and water level. This applies to the area of a joint probability curve where high water levels enable large wind waves to cause defence overtopping. Morphology is shown to be a key control regardless of sea defence failure, but larger variability exists between forcing when a breach is applied before high water. Accounting for morphology in flood modelling is therefore a critical component for reducing uncertainty under joint probability boundary conditions, particularly under high wave action. As such, storm impact modelling should either be inclusive of morphology or process input topographic datasets to smooth pre-existing features in a wave-dominated, macrotidal area's coastal geomorphology to prevent the impact of geomorphological features (e.g., intertidal swash bar systems or ridge-runnels) that are washed out during the event, dissipating the wave conditions. Uncertainties between seasonal variations in beach levels recorded by bi-annual surveys are important to determine appropriate input bathymetry. Knowledge about the most appropriate input bathymetry to select for typical or maximum overtopping conditions would better inform flood risk management by understanding the uncertainties surrounding the time of peak wave overtopping in relation to high water, the total wave overtopping volume and the resulting flood hazard and economic losses. Here, it is shown that a lower upper beach face elevation (in this case 12,705-12,760 m cross-shore distance) creates a higher overtopping hazard, even when a steep profile is present close to the structure toe, rapidly increasing the beach elevation. Whilst considerable uncertainties in determining the $H_{s}$-WL conditions of a given joint probability exist due to only short, simultaneous datasets being available, this study highlights the potential to importantly under-predict wave overtopping volume by excluding morphological evolution, even under sea defence breaching conditions.

Acknowledgments: Funded by the Engineering and Physical Sciences Research Council as part of the Adaptation and Resilience of Coastal Energy Supply project (EP/I035390/1). B.T.P. was supported by the Natural Environment Research Council's Understanding the Earth, Atmosphere and Ocean Doctoral Training Program (NE/L002469/1) whilst this manuscript was in review. Tide gauge data for Llandudno were provided by the British Oceanographic Data Centre. Liverpool Bay wave buoy data were provided by the Centre for Environment, Fisheries and Aquaculture (CEFAS). The authors would also like to acknowledge Alan Williams of Coastal Engineering UK Ltd. for providing coastal defence inspection reports and the nearshore topographic survey.

Author Contributions: The experiment was conceived of and designed by B.T.P., J.M.B. and A.J.P. J.-R.B. modelled the hourly wave hindcast data for joint probability inputs and provided comments on the paper. B.T.P. performed the experiments, analysed the data and wrote the paper along with J.M.B. and A.J.P.

Conflicts of Interest: The authors declare no conflict of interest. 


\section{References}

1. Wood, R.M.; Bateman, W. Uncertainties and constraints on breaching and their implications for flood loss estimation. Philos. Trans. R. Soc. Ser. A Math. Phys. Eng. Sci. 2005, 363, 1423-1430.

2. Van Heerden, I.L. The Failure of the New Orleans Levee System Following Hurricane Katrina and the Pathway Forward. Public Adm. Rev. 2007, 67, 24-35.

3. Bernitt, L.; Lynett, P. Breaching of sea dikes. In Proceedings of the 32nd Conference on Coastal Engineering (ICCE No 32), Shanghai, China, 30 June-5 July 2010.

4. Jonkman, S.; Masskant, B.; Boyd, E.; Levitan, M. Loss of life caused by the flooding of New Orleans after Hurricane Katrina: Analysis of the relationship between flood characteristics and mortality. Risk Anal. Off. Publ. Soc. Risk Anal. 2009, 29, 676-698.

5. Risk Management Solutions (RMS). 1953 U.K. Floods: A 50-Year Retrospective; Technical Report; Risk Management Solutions, Inc.: Newark, CA, USA, 2003.

6. Department for Environment Food and Rural Affairs (DEFRA). Flood Risks to People Phase 1, R E D Technical Report FD2317; Technical Report; Department for Environment Food and Rural Affairs: London, UK, 2003.

7. Baxter, P.J. The east coast Big Flood, 31 January-1 February 1953: A summary of the human disaster. Philos. Trans. Ser. A Math. Phys. Eng. Sci. 2005, 363, 1293-1312.

8. Wright, L.D.; Short, A.D. Morphodynamic variability of surf zones and beaches: A synthesis. Mar. Geol. 1984, 56, 93-118.

9. He, Z.; Hu, P.; Zhao, L.; Wu, G.; Pähtz, T. Modeling of breaching due to overtopping flow and waves based on coupled flow and sediment transport. Water 2015, 7, 4283-4304.

10. Wright, L.D.; Short, A.D.; Green, M.O. Short-term changes in the morphodynamic states of beaches and surf zones: An empirical predictive model. Mar. Geol. 1985, 62, 339-364.

11. Loureiro, C.; Ferreira, Ó.; Cooper, J. Contrasting morphologic behaviour at embayed beaches in Southern Portugal. J. Coast. Res. 2009, 1, 83-87.

12. Kanning, W.; van Baars, S.; van Gelder, P.H.A.J.M.; Vrijling, J.K. Lessons from New Orleans for the design and maintenance of flood defence systems. In Risk, Reliability and Societal Safety; Aven, T., Vinnem, J.E., Eds.; Taylor and Francis Group: London, UK, 2007.

13. Vorogushyn, S.; Merz, B.; Apel, H. Development of dike fragility curves for piping and micro-instability breach mechanisms. Nat. Hazards Earth Syst. Sci. 2009, 9, 1383-1401.

14. Morris, M.W.; Hassan, M. Breach Formation through Embankment Dams \& Flood Defence Embankments: A State of the Art Review, Impact Project Workshop (16-17 May 2002); Technical Report; HR Wallingford: Wallingford, UK, 2002.

15. Smallegan, S.M.; Irish, J.L.; van Dongeren, A.R.; den Bieman, J.P. Morphological response of a sandy barrier island with a buried seawall during Hurricane Sandy. Coast. Eng. 2016, 110, 102-110.

16. Hawkes, P.; Gouldby, B. The Joint Probability of Waves and Water Levels: JOIN-SEA Version 1.0; HR Wallingford: Wallingford, UK, 1998.

17. Prime, T.; Brown, J.M.; Plater, A.J. Flood inundation uncertainty: The case of a $0.5 \%$ annual probability flood event. Environ. Sci. Policy 2016, 59, 1-9.

18. Dawson, R.; Hall, J.; Sayers, P.; Bates, P.; Rosu, C. Sampling-based flood risk analysis for fluvial dike systems. Stoch. Environ. Res. Risk Assess. 2005, 19, 388-402.

19. Nicholls, R.; Mokrech, M.; Bates, P.; Dawson, R.; Hall, J. Assessing Coastal Flood Risk at Specific Sites and Regional Scales: Regional Assessment of Coastal Flood Risk; Technical Report 45; Tyndall Centre for Climate Change Research: Norwich, UK, 2005.

20. Stanczak, G.; Oumeraci, H. Model for prediction of sea dike breaching initiated by breaking wave impact. Nat. Hazards 2011, 61, 673-687.

21. D'Eliso, C.; Oumeraci, H.; Kortenhaus, A. Breaching of Coastal Dikes: Reliability Analysis and Validation of the Model System; University of Florence: Florence, Italy, 2007; p. 44.

22. Naulin, M.; Kortenhaus, A.; Oumeraci, H. Failure Probability of Flood Defence Structures/Systems in Risk Analysis for Extreme Storm Surges. Coast. Eng. 2010, 32, 1-15.

23. Wadey, M.P.; Nicholls, R.J.; Hutton, C. Coastal Flooding in the Solent: An Integrated Analysis of Defences and Inundation. Water 2012, 4, 430-459. 
24. Gervais, M.; Balouin, Y.; Belon, R. Morphological response and coastal dynamics associated with major storm events along the Gulf of Lions Coastline, France. Geomorphology 2012, 143-144, 69-80.

25. Kobayashi, N.; Tega, Y.; Hancock, M.W. Wave reflection and overwash of dunes. J. Waterw. Port Coast. Ocean Eng. 1996, 122, 150-153.

26. Baldock, T.E.; Weir, F.; Hughes, M.G. Morphodynamic evolution of a coastal lagoon entrance during swash overwash. Geomorphology 2008, 95, 398-411.

27. McCall, R.T.; van Thiel de Vries, J.S.M.; Plant, N.G.; van Dongeren, A.R.; Roelvink, J.A.; Thompson, D.M.; Reniers, A.J.H.M. Two-dimensional time dependent hurricane overwash and erosion modeling at Santa Rosa Island. Coast. Eng. 2010, 57, 668-683.

28. McCall, R.T.; Masselink, G.; Poate, T.G.; Roelvink, J.A.; Almeida, L.P.; Davidson, M.; Russell, P.E. Modelling storm hydrodynamics on gravel beaches with XBeach-G. Coast. Eng. 2014, 91, 231-250.

29. Williams, J.J.; de Alegría-Arzaburu, A.R.; McCall, R.T.; van Dongeren, A. Modelling gravel barrier profile response to combined waves and tides using XBeach: Laboratory and field results. Coast. Eng. 2012, $63,62-80$.

30. Dissanayake, P.; Brown, J.; Karunarathna, H. Modelling storm-induced beach/dune evolution: Sefton coast, Liverpool Bay, UK. Mar. Geol. 2014, 357, 225-242.

31. Roelvink, D.; Reniers, A.; van Dongeren, A.; van Thiel de Vries, J.; McCall, R.; Lescinski, J. Modelling storm impacts on beaches, dunes and barrier islands. Coast. Eng. 2009, 56, 1133-1152.

32. Laudier, N.A.; Thornton, E.B.; MacMahan, J. Measured and modeled wave overtopping on a natural beach. Coast. Eng. 2011, 58, 815-825.

33. McCabe, M.; Stansby, P.; Apsley, D. Random wave runup and overtopping a steep sea wall: Shallow-water and Boussinesq modelling with generalised breaking and wall impact algorithms validated against laboratory and field measurements. Coast. Eng. 2013, 74, 33-49.

34. Prime, T.; Brown, J.M.; Plater, A.J. Physical and economic impacts of sea-level rise and low probability flooding events on coastal communities. PLOS ONE 2015, 10, e0117030.

35. Lichter, M.; Vafeidis, A.; Nicholls, R.; Kaiser, G. Exploring Data-Related Uncertainties in Analyses of Land Area and Population in the "Low-Elevation Coastal Zone" (LECZ). J. Coast. Res. 2011, 274, 757-768.

36. Coastal Engineering UK Ltd. Denbighshire County Council Coastal Defence Monitoring Inspection December 2013; Technical Report December; Coastal Engineering UK Ltd.: Thurstaston, UK, 2013.

37. National Tidal and Sea Level Facility. Highest and Lowest Predicted Tides at Llandudno; The National Oceanography Centre: Southampton, UK, 2008.

38. Wolf, J.; Brown, J.M.; Howarth, M.J. The wave climate of Liverpool Bay-observations and modelling. Ocean Dyn. 2011, 61, 639-655.

39. HR Wallingford. Conwy Tidal Flood Risk Assessment, Stage 1- Interim Report, Report EX 4667; Technical Report; HR Wallingford: Wallingford, UK, 2003.

40. Buijs, F.; Simm, J.; Wallis, M.; Sayers, P. Performance and Reliability of Flood and Coastal Defences. RED Technical Report FD2318/TR1; Technical Report; Department for Environment Food and Rural Affairs: London, UK, 2007.

41. Parker, S. Flooding to Properties in Rhyl ( A548 Coast Road, Garford Road and Surrounding Areas) 5th December 2013; Technical Report; Denbighshire County Council: Denbigh, UK, 2014.

42. Dissanayake, P.; Brown, J.; Karunarathna, H. Impacts of storm chronology on the morphological changes of the Formby beach and dune system, UK. Nat. Hazards Earth Syst. Sci. 2015, 15, 1533-1543.

43. DigitalGlobe. Google Earth Satellite Imagery-QGIS OpenLayers Plugin; DigitalGlobe: Longmont, CO, USA, 2016.

44. Souza, A.J.; Brown, J.M.; Williams, J.J.; Lymbery, G. Application of an operational storm coastal impact forecasting system. J. Oper. Oceanogr. 2013, 6, 23-26.

45. Harley, M.D.; Valentini, A.; Armaroli, C.; Perini, L.; Calabrese, L.; Ciavola, P. Can an early-warning system help minimize the impacts of coastal storms? A case study of the 2012 Halloween storm, northern Italy. Nat. Hazards Earth Syst. Sci. 2016, 16, 209-222.

46. McMillan, A.; Batstone, C.; Worth, D.; Tawn, J.; Horsburgh, K.; Lawless, M. Coastal Flood Boundary Conditions for UK Mainland and Islands. Project SC060064/TR2: Design Sea Levels; Environment Agency: Bristol, UK, 2011.

47. European Centre for Medium Range Weather Forecasts. IFS Documentation I ECMWF; European Centre for Medium Range Weather Forecasts: Reading, UK, 2016. 
48. Natural Resources Wales. Natural Resources Wales/Flood Risk Map; Natural Resources Wales: Cardiff, UK, 2015.

49. Wadey, M.P.; Brown, J.M.; Haigh, I.D.; Dolphin, T.; Wisse, P. Assessment and comparison of extreme sea levels and waves during the 2013/14 storm season in two UK coastal regions. Nat. Hazards Earth Syst. Sci. 2015, 15, 2209-2225.

50. National Tidal and Sea Level Facility. Storm Surge Climatology: Wales; National Tidal and Sea Level Facility: Liverpool, UK, 2012.

51. Scott, T.; Masselink, G.; Russell, P. Morphodynamic characteristics and classification of beaches in England and Wales. Mar. Geol. 2011, 286, 1-20.

52. Stansby, P.; Chini, N.; Apsley, D.; Borthwick, A.; Bricheno, L.; Horrillo-Caraballo, J.; Mccabe, M.; Reeve, D.; Rogers, B.D.; Saulter, A.; et al. An integrated model system for coastal flood prediction with a case history for Walcott, UK, on 9 November 2007. J. Flood Risk Manag. 2013, 6, 229-252.

53. Silveira, T.M.; Taborda, R.; Carapuço, M.M.; Andrade, C.; Freitas, M.C.; Duarte, J.F.; Psuty, N.P. Assessing the overwash regime along an embayed urban beach. Geomorphology 2016, Accepted.

54. Gallien, T.W. Validated coastal flood modeling at Imperial Beach, California: Comparing total water level, empirical and numerical overtopping methodologies. Coast. Eng. 2016, 111, 95-104.

55. Prime, T.; Brown, J.M.; Knight, P.J.; Plater, A.J. Sandscaping for Mitigating Coastal Flood and Erosion Risk to Energy Infrastructure on Gravel Shorelines: Dungeness Flood Risk Assessment; Technical Report Research \& Consultancy Report No. 49; National Oceanography Centre: Southampton, UK, 2015.

56. EDF Energy Nuclear Generation Ltd. (EDF). EU Stress Test-Dungeness B; EDF Energy Nuclear Generation Ltd.: Barnwood, UK, 2012.

57. Wadey, M.P.; Haigh, I.D.; Nicholls, R.J.; Brown, J.M.; Horsburgh, K.; Carroll, B.; Gallop, S.L.; Mason, T.; Bradshaw, E. A comparison of the 31 January-1 February 1953 and 5-6 December 2013 coastal flood events around the UK. Front. Mar. Sci. 2015, 2, doi:10.3389/fmars.2015.00084.

(C) 2017 by the authors; licensee MDPI, Basel, Switzerland. This article is an open access article distributed under the terms and conditions of the Creative Commons Attribution (CC-BY) license (http://creativecommons.org/licenses/by/4.0/). 